JURNAL PENDIDIKAN USIA DINI

DOI: https://doi.org/10.21009/JPUD.112
DOI: https://doi.org/10.21009/JPUD.112.13

\title{
MODEL PEMBELAJARAN RENANG (FH) BAGI SISWA PRASEKOLAH
}

\author{
WIDIASTUTI' ${ }^{1}$ FATIN HAMAMAH ${ }^{2}$ \\ Pendidikan Olahrga Universitas Negeri Jakarta ${ }^{1}$ \\ Mahasiswa Pascasarjana $\mathrm{UNJ}^{2}$ \\ Email: widi_harun@yahoo.com \\ fatintivien@gmail.com
}

\begin{abstract}
The objective of this research is to generate a pool of learning model for students preschool. The method used in this reaseach and development model from Borg and Gall. The Instruments used in the research of this model are questionnaires and pool Assesment instruments for students preschool used to collect data at the stage of : (1) analysis of needs; (2) the expert evaluation (initial product evaluation); (3) Tests small groups; (4) Friendlies large groups. Test the effectiveness of the model using the swimming assessment tests for students preschool to see improved results of swimming skills before applying the learning model created. Based on the results obtained between yield enhancement swimming skills before applying the learning model pool total 64.3\%, and after being given treatment by using model new pool design researchers increased to $93.25 \%$. Based on the research results can be concluded with the pool learning model for preschool students, students can learn effectively and efficiently.
\end{abstract}

Key Word: Development, Model, Swimming

\begin{abstract}
Abstrak, Tujuan penelitian ini adalah untuk menghasilkan model pembelajaran renang bagi siswa prasekolah. Metode yang digunakan dalam penelitian ini adalah model penelitian dan pengembangan (Research and Development) dari Borg dan Gall. Instrumen yang digunakan dalam penelitian model ini adalah kuisioner dan instrumen penilaian renang bagi siswa prasekolah yang digunakan untuk mengumpulkan data pada tahap: (1) analisis kebutuhan; (2) evaluasi ahli (evaluasi produk awal); (3) Ujicoba kelompok kecil; (4) Ujicoba kelompok besar. Uji efektifitas model menggunakan tes penilaian renang bagi siswa prasekolah dengan melihat peningkatan hasil keterampilan renang sebelum diterapkannya model pembelajaran. Berdasarkan hasil yang didapat peningkatan antara hasil keterampilan renang sebelum diterapkannya model pembelajaran renang total $64,3 \%$ dan setelah diberikan perlakuan dengan menggunakan model pembelajaran renang yang baru desain peneliti meningkat menjadi 93,25\%. Berdasarkan hasil penelitian dapat disimpulkan dengan model pembelajaran renang FH bagi siswa prasekolah, siswa dapat belajar secara efektif dan efisien.
\end{abstract}

Kata kunci: Pengembangan, Model, Renang 


\section{PENDAHULUAN}

Cabang olahraga renang menjadi salah satu olahraga yang sangat populer dan digemari oleh banyak kalangan, terutama di kotakota besar yang terdapat fasilitas olahraga yang cukup lengkap. Olahraga renang diminati oleh semua tingkat usia mulai dari anak-anak, remaja sampai dewasa. Dengan berbagai kebutuhan yang berbeda diantaranya: Mengisi waktu luang, menjaga kebugaran tubuh, rekreasi, serta prestasi dan sebagai sarana pendidikan.

Olahraga renang termasuk dalam jenis olahraga aquatik yang diajarkan di sekolah. Maka, tugas dari seorang guru pendidikan jasmani harus mengajarkannya. Olahraga renang dapat memberikan kesempatan kepada siswa untuk memahami serta beradaptasi terhadap lingkungannya.

Proses pembelajaran merupakan bentuk usaha yang dilakukan untuk memperbaiki kualitas pembelajaran guna mencapai tujuan yang diharapkan. Dalam proses pembelajaran pendidikan jasmani diperlukan pengetahuan tentang karakteristik pertumbuhan dan perkembangan peserta didik, prinsip-prinsip belajar gerak, materi yang akan diajarkan, metode atau pendekatan yang digunakan, serta pendukung lainnya agar proses pembelajaran dapat terlaksana dengan baik dan tujuan ditetapkan. Proses pembelajaran perlu memperhatikan masukan instrumental yang meliputi kurikulum, program, materi sarana dan prasarana, fasilitas, serta metode dan penilaian. Disamping itu diperlukan pula suatu model pembelajaran pendidikan jasmani, olahraga dan kesehatan.

Menurut Moston dan Ashworth dalam Rosdiani (2014) Proses belajar mengajar merupakan interaksi berkelanjutan antara perilaku guru dan perilaku peserta didik. Dalam penerapan guru pendidikan jasmani sering mengabaikan atau tidak memperhatikan prinsip pengajaran pendidikan jasmani yang bersuasana sesuai dengan tingkat umur peserta didik prasekolah, dan masih banyak melakukan pemberian materi dengan cara lama atau tradisional.

Setiap guru mempunyai cara masing-masing dalam memilih dan 
Model Pembelajaran Renang......... Widiastuti \& Fatin

menentukan aktivitas belajarnya. Maka, guru harus mengembangkan keberanian dan kesenangan siswa terhadap air. Kegiatan ini merupakan kondisi yang sangat baik dalam rangka menumbuhkan bentuk-bentuk aktivitas belajar olahraga renang.

\section{KAJIAN TEORITIK \\ Belajar Renang pada anak Prasekolah}

Kemampuan yang diperoleh seseorang setelah melakukan kegiatan belajar dinamakan hasil belajar. Menurut Tangkudung (2012:9) dalam usaha untuk mencapai prestasi yang cepat, pengajar atau pelatih menekankan pada anak-anak pada latihan yang intensif dan spesifik tanpa membentuk dasar yang baik, ini seperti membangun gedung bertingkat namun pondasi lemah yang mengakibatkan robohnya bangunan tersebut.

Dengan teori dan konsep olahraga yang ada di harapkan akan memberikan kontribusi pada peningkatan prestasi olahraga di Indonesia, sedangkan perhatian yang dicurahkan untuk mempelajari belajar dan berpenampilan motorik dalam usaha meningkatkan dalam usaha

meningkatkan prestasi olahraga berkembang pesat pada saat ini. Menurut Sunarto dan Agung (2005: 5) Seorang anak mungkin memulai pendidikan formalnya di tingkat taman kanak-kanak pada usia 4 atau 5 tahun. Pada awal memasuki sekolah mungkin tertunda sampai berusia 5 atau 6 tahun. Tanpa memperdulikan berapa umur seorang anak, karakteristik pribadi dan kebiasaan-kebiasaan yang dibawanya ke sekolah akhirnya terbentuk oleh pengaruh lingkungan dan itu tampaknya mempunyai pengaruh penting terhadap keberhasilannya di sekolah dan masa perkembangan hidupnya di kelak kemudian.

Eileen dan Lynn (2010:145) mendefinisikan Bermain dan kegiatan sosial merupakan rutinitas sehari-hari yang dilakukan oleh siswa prasekolah. Siswa prasekolah selalu aktif bergerak setiap saat dan ingin belajar mengenai segala sesuatu. Membutuhkan banyak dukungan dan persetujuan orang dewasa, walaupun kebutuhan ini menjadi tidak terlalu jelas ketika keluar dari prasekolah dan masuk ke sekolah dasar. Keluarga dan guru memegang peran penting dalam memberikan bimbingan dan 
jenis kesempatan pembelajaran yang memungkinkan siswa prasekolah untuk berlatih, memperbaiki dan mengembangkan sejumlah keterampilan yang mencerminkan perkembangan yang sehat. Sementara itu, orang dewasa harus membuat batasan untuk melindungi dari kemungkinan bahaya yang ditimbulkan oleh kegembiraannya yang meluap-luap dan tekadnya untuk tumbuh yang justru dapat membahayakan anak itu sendiri atau orang lain.

Berdasarkan beberapa teori di atas maka bisa ditarik kesimpulan bahwa pertumbuhan dan perkembangan siswa prasekolah merupakan suatu kesatuan dan menyeluruh. Dalam kegiatan pembelajaran atau pelaksanaan program hal ini juga tidak dapat dipisah-pisah, namun untuk memudahkan guru atau orang tua dan yang lainnya merancang kegiatan pembelajaran atau pelaksanaan program perlu mengidentifikasi pertumbuhan dan perkembangan siswa.

Olahraga renang merupakan olahraga air yang sangat populer dan digemari masyarakat dari masa ke masa, terutama di kota-kota besar yang tersedia fasilitas olahraga yang cukup lengkap. Menurut Husni (2005:318) Olahraga renang adalah olahraga yang menyehatkan sebab hampir semua otot tubuh bergerak dan berkembang dengan mengkoordinasikan kekuatan setiap perenang

Evans (2007:1) mengatakan "Swimming is an activity many people have done virtually their entire lives. Kids look forward to days at the pool, lake, or ocean, splashing around and racing friends" dari penjelasan tersebut dijelaskan bahwa berenang merupakan aktivitas yang telah dilakukan banyak orang seumur hidup mereka. Anak-anak sangat senang bermain di kolam renang, danau, atau lautan, banyak aktivitas yang dapat dilakukan ketika mereka di air yang akan membuat mereka menjadi senang.

Mulyana

menjelaskan bahwa Olahraga renang termasuk salah satu keterampilan yang harus dipelajari terutama bagi anak-anak. Keterampilan renang dikuasai melalui proses belajar dan bukan kematangan. Belajar renang adalah proses awal individu mulai 
Model Pembelajaran Renang......... Widiastuti \& Fatin

mengenal air dan menguasai teknik dasar renang yang baik, seperti pernapasan, meluncur dan mengapung.

Olahraga ini diminati oleh semua tingkat usia baik dari orang dewasa, remaja, dan tidak terkecuali dengan anak-anak yang menantikan hari dimana mereka dapat bermain dikolam renang dengan temantemannya seperti berkeliling di area kolam renang bahkan berkompetisi berenang.

Olahraga renang termasuk salah satu keterampilan yang harus dipelajari terutama bagi anak-anak. Keterampilan renang dikuasai melalui proses belajar dan bukan kematangan. Seperti yang dikatakan Mulyana (2015:4) Belajar renang adalah proses awal individu mulai mengenal air dan menguasai teknik dasar renang yang baik, seperti pernapasan, meluncur dan mengapung.

Karakteristik Siswa Prasekolah (46 tahun)

Setiap individu memiliki ciri dan sifat atau karakteristik bawaan dan karakteristik yang diperoleh dari Pengaruh lingkungan. Lingkungan menjadi salah satu faktor yang mempengaruhi perkembangan anak.

Oleh karena itu lingkungan perlu dirancang sedemikian rupa agar dapat mengembangkan dan menyempurnakan apa yang dibawa anak sejak lahir. Rancangan itu dapat dilakukan di rumah, di sekolah, atau dimana saja.

Karakteristik bawaan merupakan karakteristik keturunan yang dimiliki sejak lahir, baik yang menyangkut faktor biologis maupun faktor sosial psikologis. Karakteristik bawaan dan lingkungan masingmasing mempengaruhi kepribadian dan kemampuan individu. Sunarto dan Agung (2005 :18) Setiap individu hakikatnya akan mengalami pertumbuhan fisik dan nonfisik yang meliputi aspek-aspek intelek, emosi, sosial, bahasa, bakat khusus, nilai dan moral, serta sikap.

Pendidikan anak prasekolah di Indonesia, khususnya taman kanak-kanak, telah diselenggarakan sejak lama, yaitu sejak awak kemerdekaan Indonesia. Di sekolah ini, anak usia 4-5 atau 6 tahun mendapatkan tempat untuk mengembangkan potensi-potensi yang dimiliki dalam berbagai bentuk belajar dalam bermain. Bentuk 
kegiatan ini diwujudkan dalam berbagai ekspresi diri secara kreatif.

Menurut

Morisson

(2012:221) Pada tahap prasekolah, anak sepenuhnya terlibat dalam aktivitas perpindahan dan kesenangan melakukan banyak hal. Sangat aktif dan ingin mengikuti semua aktivitas. Ingin bergerak dan menjadi aktif.

Usia prasekolah penuh energi, antusiasme dan rasa ingin tahu. Keterampilan motorik mereka semakin sempurna, kreativitas dan imajinasi muncul dam segala hal, drama, karya seni sampai bercerita. Kosakata dan keterampilan intelektual berkembang secara pesat, memungkinkan anak mengekspresikan gagasannya, memecahkan masalah, dan membuat rencana. Anak prasekolah sangat percaya pada pendapat mereka sendiri. Sementara itu, tumbuh perasaan kebutuhan akan orang lain dan mulai ada pengendalian terhadap perilaku sendiri.

Siswa prasekolah yang berusia 4-5 atau 6 tahun memiliki energi yang tinggi. Energi ini dibutuhkan untuk melakukan berbagai kegiatan yang diperlukan dalam meningkatkan keterampilan fisik, baik yang berkaitan dengan peningkatan keterampilan motorik kasar, seperti berlari, melompat, bergantung, melempar bola dan menendangnya maupun motorik halus. Sebagaimana menurut Jamaris (2006:6) Kegiatan fisik dan pelepasan energi dalam jumlah besar ini merupakan karakteristik aktivitas anak pada masa ini.

Perkembangan fisik pada masa ini ditandai dengan berkembangnya motorik, baik motorik kasar maupun halus. Sekitar usia 3 tahun anak sudah dapat berjalan dengan baik dan seklitar 4 tahun anak hampir menguasai cara berjalan orang dewasa. Perkembangan motorik dibagi menjadi dua yaitu, motorik kasar dan motorik halus.

Menurut Piaget (2010:22) pada perkembangan kognitif ini dinamakan tahap pra-operasional yang berlangsung dari usia 2-7 tahun. Pada tahap ini konsep yang stabil dibentuk. Penalaran mental muncul, egosentris mulai kuat dan kemudian mulai melemah, serta terbentuknya keyakinan terhadap hal yang magis. Pada masa ini anak difokuskan pada keterbatasan pemikiran. Menunjukan 
Model Pembelajaran Renang......... Widiastuti \& Fatin

pada aktifitas mental yang normal hanya bertambah 2,5-3,5 memungkinkan anak untuk kilogram setahun.

memikirkan peristiwa pengalaman

Berdasarkan dari karakteristik yang dialaminya.

Perkembangan fisik anak usia

4-6 tahun selain berkembangnya gerakan motorik kasar baik keterampilan lokomotorik (melompat, meluncur, berguling, menderap, berhenti, berjalan, dan mengelak). Keterampilan nonlokomotorik (berayun, berbelok, mengangkat, bergoyang, memeluk, melengkung, memutar dan mendorong). Keterampilan memproyeksi, menangkap, dan menerima. Maupun motorik halus perkembangan otak dan susunan syaraf pusatnya juga ikut berkembang. Selain itu perkembangan tubuhnya juga ikut berkembang, pertambahan tinggi badan anak bertambah 2,5 inci siswa prasekolah di atas, diajak untuk bereksplorasi, menentukan memanfaatkan objek-objek yang dekat dengannya sehingga pembelajaran menjadi bermakna. Tanggungjawab guru untuk menciptakan lingkungan yang memastikan peserta didik mendapatkan pengalaman yang bermakna dan menyenangkan.

METODE PENELITIAN

Penelitian pengembangan model pembelajaran renang ini menggunakan model penelitian dan pengembangan (Research and Development) dari Borg dan Gall (1983:775) yang terdiri dari sepuluh langkah dalam penelitianyakni antara lain:

setahun dan berat badan secara

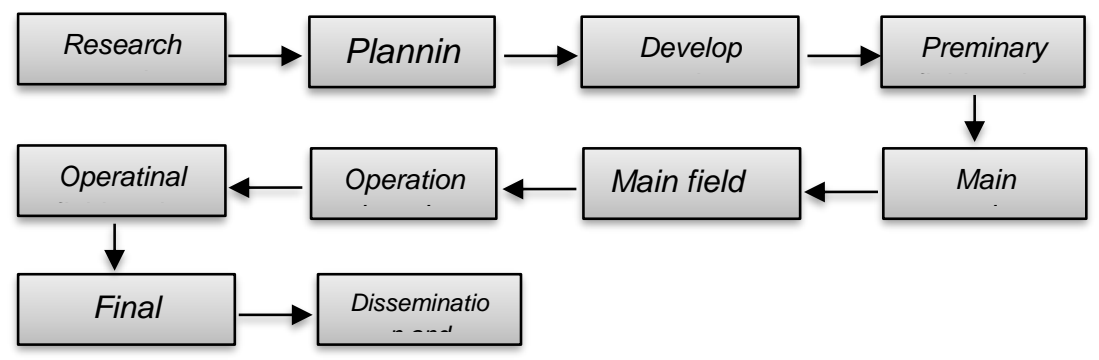

Gambar 1. Langkah-Langkah Pengembangan Borg, W.R dan Gall, M.D 
HASIL DAN PEMBAHASAN

Secara keseluruhan terdapat dua tujuan umum yang hendak diungkapkan dalam studi pendahuluan, yaitu: (1) Seberapa intens pembelajaran pendidikan jasmani khususnya pada materi akuatik sejalan dengan karakteristik implementasi kurikulum seperti yang telah dirumuskan; (2) Seberapa penting pengembangan pembelajaran renang dengan model pengembangan pembelajaran renang dengan model pengembangan variasi pembelajaran dalam proses pembelajaran yang efektif dan efisien, serta menarik.

Peneliti melakukan penelitian awal atau analisis kebutuhan yang dilaksanakan pada tanggal 14 Maret 2016, peneliti melakukan observasi menggunakan intrumen penilaian kemampuan dasar renang siswa prasekolah dan wawancara terhadap guru prasekolah mengenai model pembelajaran renang di salah satu sekolah Taman Kanak-kanak. Dari hasil analisis kebutuhan tersebut dapat diketahui bahwa: (1) Lebih dari $60 \%$ siswa mengalami kesulitan dalam belajar berenang, (2) Guru menyatakan perlunya variasi model pembelajaran renang untuk dimasukan dalam proses pembelajaran, khususnya saat materi aquatik. Dari paparan hasil penelitian awal analisis kebutuhan diatas maka dapat disimpulkan bahwa pentingnya variasi model pembelajaran renang bagi siswa prasekolah. Berikut ini hasil nilai renang sebelum dan sesudah treatment atau perlakuan:

Berikut perbandingan hasil dari tingkat kemampuan dasar peserta didik sebelum pemberian treatment dan sesudah pemberian treatment dengan model-model pembelajaran renang bagi siswa prasekolah dengan diagram batang: 


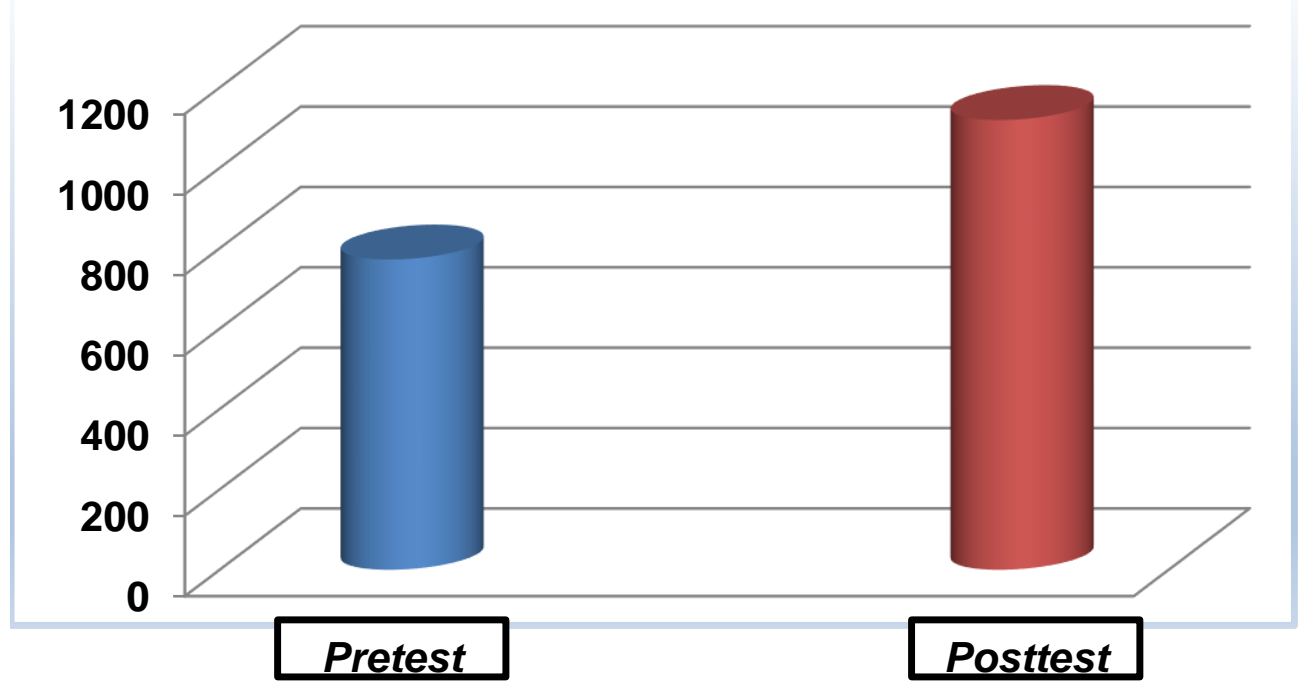

Gambar 2. Diagram Batang (Uji Coba Kelompok Besar)

Hasil ujicoba kelompok kecil dan kelompok besar dapat disimpulkan bahwa model pembelajaran renang bagi siswa prasekolah dapat digunakan dalam pembelajaran renang bagi siswa prasekolah serta layak dan efektif untuk meningkatkan kemampuan dasar renang.

Berdasarkan perolehan angka pada tabel di atas maka dapat disimpulkan bahwa model pembelajaran renang bagi siswa prasekolah dapat dan layak untuk digunakan dalam pembelajaran renang bagi siswa prasekolah serta efektif untuk meningkatkan kemampuan dasar renang. Terdapat perbandingan angka yang menunjukan hasil tes awal dan tes akhir mengalami perkembangan, dari tes awal atau Pretest yang berjumlah 772, kemudian diberikan perlakuan berupa model-model pembelajaran renang yang sudah dikembangkan kemudian dilanjutkan tes akhir atau Pretest untuk mengetahui efektivitas model yang dikembangkan efektif untuk mengembangkan kemampuan dasar renang siswa prasekolah. Model ini dibuat berdasarkan tingkat kebutuhan peserta didik dalam aktivitas gerak, yang secara psikologis siswa prasekolah ini lebih senang dengan aktivitas bermain, maka dalam model ini penerapannya dilakukan dengan prinsip pendekatan bermain.

Produk yang dikembangkan ini bertujuan untuk membentuk meningkatkan tercapainya tujuan 
pembelajaran renang bagi siswa prasekolah

Produk ini setelah dikaji mengenani beberapa kelemahan yang perlu pembenahan sesuai diatas maka dapat disampaikan beberapa keunggulan produk ini antara lain (1) Siswa lebih aktif dalam mengikuti proses belajar sambil bermain. (2) Siswa terlihat gembira dan antusias. (3) Model pembelajaran dilakukan dari yang mudah ke yang sulit. (4) Tingkat kompetisi yang tinggi sehingga membuat siswa lebih bersemangat. (5) Memerlukan saranan yang lebih banyak dari pembelajaran konvensional tetapi mampu diterapkan sesuai denga karakteristik siswa prasekolah.

\section{KESIMPULAN}

Berdasarkan data yang diperoleh, dari hasil penelitian yang terdiri dari validasi ahli, uji coba kelompok kecil dan uji coba kelompok besar serta pembahasan dari hasil penelitian, maka peneliti dapat menarik kesimpulan bahwa (1) Model pembelajaran yang diperoleh secara keseluruhan dari ahli pembelajaran pendidikan jasmani menyatakan bahwa model yang dibuat termasuk dalam kategori baik dan layak digunakan (2) Model yang diperoleh secara keseluruhan dari ahli renang menyatakan bahwa model yang dibuat termasuk dalam kategori baik dan layak digunakan. (3) Uji coba kelompok kecil dan kelompok besar dinyatakan efektif untuk digunakan. (4) Model pembelajaran renang bagi siswa prasekolah dapat dikembangkan dan diterapkan dalam pembelajaran akuatik serta meningkatkan peran aktif siswa prasekolah dalam aktivitas fisik. (5) Model pembelajaran renang bagi siswa prasekolah yang telah peneliti kembangkan, diperoleh data efektifitas dari hasil pengembangan model pembelajaran renang bagi siswa prasekolah.

\section{DAFTAR PUSTAKA}

Sunarto, Agung, Perkembangan Peserta Didik. Jakarta: Rineka Cipta. 2005.

Mulyana, Dadan Pelatihan Cabang Olahraga Renang. Disajikan pada kegiatan peningkatan tenaga keolahragaan melalui pelatihan pelatih renang tingkat provinsi Jawa Barat.Bandung: UPI. 2015.

Rosdiani, Dini, Perencanaan Pembelajaran dalam Pendidikan Jasmani dan 
Model Pembelajaran Renang. . .

Widiastuti \& Fatin

Kesehatan. Bandung: $\quad$ Evans, Janet, Total Swimming.

Alfabeta. 2014.

Canada United Graphics. 2007

Lynn, Eileen, Profil Perkembangan Anak Pra Kelahiran Hingga Usia 12 Tahun. Jakarta: PT. Indeks. 2010.

Jamaris, Martini. Perkembangan dan Pengembangan Anak Usia Taman Kanak-Kanak. 2006 